\title{
Community structure of mangrove in Lambadeuk village, Aceh Besar regency, Indonesia
}

\author{
Chitra Octavina ${ }^{1,2,3^{*}}$, Maria Ulfah $^{1,2,3}$, Rauzatul Sakinah ${ }^{1}$, Sayed Abdul Azis ${ }^{4,5}$, Nanda Muhammad Razi ${ }^{4,5}$, Muhammad $^{2}$ \\ Rizki Fazillah ${ }^{1,4}$, and Muhammad Agustiar ${ }^{1,4}$ \\ ${ }^{1}$ Department of Marine Sciences, Faculty of Marine and Fisheries, Universitas Syiah Kuala, Indonesia \\ ${ }^{2}$ Research Center for Marine and Fisheries, Universitas Syiah Kuala, Indonesia \\ ${ }^{3}$ Marine Biology Laboratory, Faculty of Marine and Fisheries, Universitas Syiah Kuala, Indonesia \\ ${ }^{4}$ Ocean Diving Club, Faculty of Marine and Fisheries, Universitas Syiah Kuala, Indonesia \\ ${ }^{5}$ Masters Program in Integrated Coastal Resource Management, Postgraduate Program, Universitas Syiah Kuala, Indonesia
}

\begin{abstract}
Mangroves are plants that can live in tidal areas. The study aims to determine the condition of the mangrove ecosystem through a mangrove community structure approach in Lambadeuk Village, Peukan Bada District, Aceh Besar District. This research was conducted in November 2017 using the stratified sampling method. The results showed that there were only 2 types of mangrove species found in Lambadeuk Village, Peukan Bada District, Aceh Besar District, the first is Rhizophora apiculata as many as 36 individuals and the second one is Rhizophora mucronata as many as 116 individuals. The important value index (INP) tree and sapling of Rhizophora apiculata at station 1 and station 3 of $253.655 \%$ and station 2 of $183.789 \%$. While seedling of Rhizophora apiculata at station 1 and station 3 of $250.04 \%$ and station 2 of $175.02 \%$. The important value index (INP) tree and sapling of Rhizophora mucronata at station 1 and station 3 of $253.655 \%$. While seedling of Rhizophora mucronata at station 1 and station 3 of $250.04 \%$. The diversity $\left(\mathrm{H}^{\prime}\right)$ obtained is low where $\mathrm{H}^{\prime} 2.0$, dominance $(\mathrm{C})$ is low where $0<\mathrm{C} 0.5$ and evenness (E) is also low where $0<$ E 0.5 .
\end{abstract}

\section{Introduction}

The mangrove ecosystem is a vegetation in the tropics invalue as a unique ecosystem, which can live in water with high salinity, and are usually found along the tidal areas [7]. Mangrove forests are the main ecosystem that supports life in coastal and marine areas. The mangrove ecosystem has important ecological function as a place habitat (feeding ground, nursey ground), (spawning ground) for a variety of marine organisms, as well as a carbon sink [16]. Ecosystem also has a physical function as anchoring coastal erosion, protecting against wind and tsunami, absorbing waste, preventing water intrusion sea. In addition, the mangrove forests also contribute economically high as providers of wood, medicines, tools and fishing locations [6].

Aceh Besar District is an area located at the northern tip of Aceh Province with a coastline of $344 \mathrm{~km}$ which is rich in biodiversity [5], one of which is mangroves. The potential of mangrove resources can be founded in Lambadeuk Village, Peukan Bada District, Aceh Besar Regency. But most of the mangrove area in the village have been damaged due to the impact and Tsunami disaster in 2004, so that rehabilitation efforts are managed by the government. According to [8], the rehabilitation program is a solution in re-functioning the damaged mangrove ecosystem. In fact, the rehabilitation efforts carried out have not been maximal.

Awareness of local communities in conserving the coastal environment is still lacking, waste disposal and pond waste are not managed properly. In addition, there are no regulations to prohibit community activities that can damage mangrove plants, such as fishpond in the mangrove rehabilitation area. The research reporting on the condition of mangroves in Lambadeuk Village, Peukan Bada District is still limited. A related study reported by [2] who studied the spatial distribution of mangroves using a geographic information system. However, research has never been done at the location. There are some observations in peukan bada district. Therefore, this study aims to determine the condition of the ecosystem mangrove through a community structure approach in Lambadeuk Village, Peukan Bada District, Aceh Besar District.

\section{Materials and Methods}

\subsection{Time and Place}

The research was conducted in November 2017 in Lambadeuk Village, Peukan Bada District, Aceh Besar District. Sample identification was carried out at the

\footnotetext{
* Corresponding author: chitraoctavina@unsyiah.ac.id
} 
Marine Biology Laboratory, Faculty of Marine and Fisheries, USK. Figure 1.

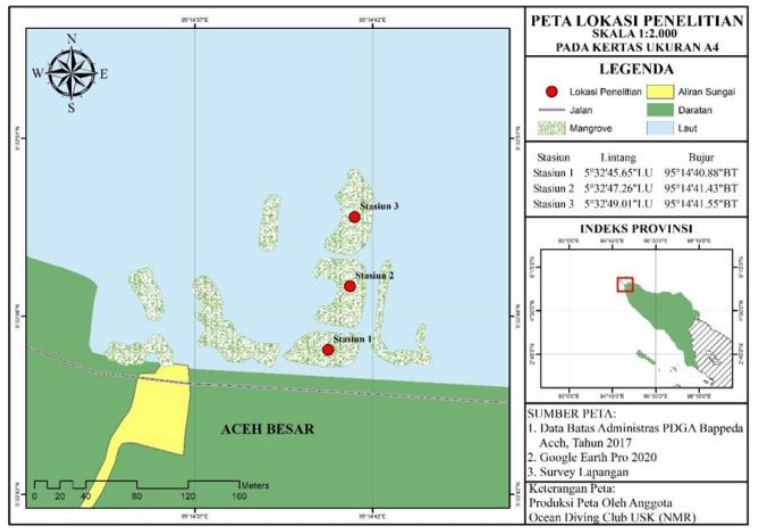

Fig. 1. Map of research locations

\subsection{Determination of research Locations}

The research locations were determined using the stratified sampling method, based on the needs and representation of the research area as a whole. Designated study area grouped into three observation in which stations are Station 1 area of mangrove vegetation was seaward Station 2 and Station 3 landward. Taking coordinates were marked by using GPS (Global Positioning System).

\subsection{Data Collection}

The stations were transected perpendicularly from sea to land. Stations are grouped into three plots. Mangrove vegetation is observed and recorded the number and type of stem diameter measured by each vegetation category. Observations on $10 \times 10 \mathrm{~m}^{2}$ plots for mangrove vegetation trees with measuring high categories $>1.5 \mathrm{~m}$ and diameter $>10 \mathrm{~cm}$. Plot $5 \times 5 \mathrm{~m}^{2}$ for the mangrove tree category with a height of $1.5 \mathrm{~m}$ and a diameter of $<10$ $\mathrm{cm}$. While plot $1 \times 1 \mathrm{~m}^{2}$ for the category of mangrove seeds with high stem $<1.5 \mathrm{~m}[11]$.

\subsection{Data Analysis}

\subsubsection{Species Density (Di) and Relative Density} (RDi)

Density and relative density of mangroves were calculated based on the equations of [9] as follows:

$$
\mathrm{Di}=\frac{N \mathrm{i}}{A}
$$

Description:

Di : Density of species i (ind/ $\mathrm{m}^{2}$ )

$\mathrm{Ni}$ : Total number of individuals of species $\mathrm{i}$ (ind)

A : Total area of sampling $\left(\mathrm{m}^{2}\right)$

$$
\mathrm{RDi}=\frac{n \mathrm{i}}{\sum \mathrm{n}} \times 100 \%
$$

Information :

RDi: Relative Density (\%)

$\mathrm{n}$ : Total number of individuals (ind)

\subsubsection{Species Frequency (Fi) and Relative Species(RFi)}

The Frequency of species and the frequency of mangrove species is calculated based on the equation [9] as follows:

$$
\mathrm{Fi}=\frac{P \mathrm{i}}{\sum \mathrm{p}}
$$

Description:

Fi :Frequency Type i (ind) pi :Number of sample plots where the i-th type is found $\mathrm{p}$ :Total number of sample plots made

$$
R F i=\frac{F \mathrm{i}}{\sum \mathrm{F}} \times 100 \%
$$

Note:

RFi : Relative Frequency (\%)

$\mathrm{p}$ : Total frequency for all species (ind)

\subsubsection{Species Coverage (Ci) and Relative Species (RCi) Species}

Cover and relative mangrove species cover are calculated based on the [9] equation as follows:

$$
C i=\frac{\sum \mathrm{BA}}{\mathrm{A}}
$$

Description:

Ci: The extent of the type of to-i $\left(\mathrm{m}^{2}\right)$

$\pi: 3.14$

$$
B A=\frac{\mathrm{DBH} 2}{4}
$$

$$
R C i=\frac{\mathrm{Fi}}{\sum \mathrm{F}} \times 100 \%
$$

Description:

RCI: Percentage of mangrove cover $(\%)$

$\mathrm{C}:$ Total area covered by all species $\left(\mathrm{m}^{2}\right)$

\subsubsection{Importance Value Index (INP)}

The mangrove significance index is calculated based on the equation of [9] as follows:

Note:

$$
\mathrm{INP}=\mathrm{RDi}+\mathrm{RFi}+\mathrm{RCi}
$$

INP: Significant Value Index (\%)

RDi: Relative Density (\%)

RFi : Relative Frequency (\%)

RCi : Relatively Important Closure (\%)

\subsubsection{Species Diversity Index ( $\left.H^{\prime}\right)$}

The mangrove species diversity index was calculated based on the equation of [24] as follows: 


$$
H^{\prime}=\sum_{i=1}^{s} P i \log 2 P i
$$

Note:

$\mathrm{H}^{\prime}$ : Diversity Index

$\mathrm{Pi}$ : Proportion of the number of individuals of the species (ni) to the total number of individuals (n)

$\mathrm{S}:$ Number of taxa/species (ind)

\subsubsection{Species Evenness Index (E)}

The mangrove species uniformity index is calculated based on the [17] equation as follows:

$$
E=\frac{H^{\prime}}{\log 2 S}
$$

Description:

E : Evenness Index

$\mathrm{H}$ :diversity index

Log2S: $3.3219 \log \mathrm{S}$

$\mathrm{S} \quad$ : Number of species (ind)

\subsubsection{Species Dominance Index (D)}

The dominance index of mangrove species is calculated based on the equation [3] as follows:

$$
D=\sum_{i=1}^{s}\left(\frac{n i}{n}\right)^{2}
$$

Description:

D : Dominance Index, Ni: Number of individuals of the species

$\mathrm{N}$ : Total number of individuals (ind)

$\mathrm{S}:$ Number of taxa/species (ind)

\section{Results and Discussion}

The Peukan Bada area is one of the natural mangrove forest areas. In this study, mangrove vegetation was divided into 3 categories, namely trees, saplings and seedlings. Based on observations at the research site, there are 2 types of mangroves located in Lambadeuk village, Peukan Bada sub-district, Aceh Besar district, namely of species Rhizophora apiculata and Rhizophora mucronata. At station 1, there were two types of mangroves, namely Rhizophora mucronata and Rhizophora apiculata species. The number of each tree category, saplings and seedlings found at Station 1 is 61 individuals at station 2 there is only one type of mangrove, from Rhizophora Apiculata. The number of each tree category, sapling and seedling contained in plot 2 of 20 stems. While at station 3 there were two species of mangroves of the same genus. The number of each category of trees, saplings and seedlings contained at station 3 is 61 stems. This research was conducted at 3 different stations with $10 \times 10 \mathrm{~m}^{2}$ tree category, $5 \times 5 \mathrm{~m}^{2}$ sapling category and $1 \times 1 \mathrm{~m}^{2}$ seedling.

The overall density value for the growth rate of trees and saplings was higher than the seedling level. The results of the study stated that the value of species density (Di) at station 1 Rhizophora apiculata of 0.08 ind $/ \mathrm{m}^{2}$. While Rhizophora mucronata of $0.53 \mathrm{ind} / \mathrm{m}^{2}$. Station 2 there is only 1 type, namely Rhizophora apiculata with a value of $0.2 \mathrm{ind} / \mathrm{m}^{2}$. Then station 3 there were 2 types, for Rhizophora apiculata the value of 0.08 $\mathrm{ind} / \mathrm{m}^{2}$. while for Rhizophora mucronata of $0.53 \mathrm{ind} / \mathrm{m}^{2}$ (Table 1). The two types of mangroves Rhizophora apiculata and Rhizophora mucronata were included in the true mangrove category (Table 2) $[4,16]$.

The greater the density of a species in Lambadeuk, the more individuals of that species per unit area. The density value can be used to see the magnitude of the disturbance to a habitat [23]. Plant habitats are considered damaged, if the value of the density of plant species is low or small.

Species frequency is one of the vegetation parameters that can show the distribution pattern or distribution of plant species in the ecosystem or show the distribution pattern of plants. The frequency value is influenced by the value of the plot where mangrove species are found. The greater the number of squares found, the higher the frequency of mangrove species presence [10]. Species frequency values (Fi) at stations 1 and 3 for Rhizophora apiculata and Rhizophora mucronata was 1 ind. The value of the species frequency Fi at station 2 for Rhizophora apiculata was 100 ind. The results of the analysis of the relative frequency (RFi) of mangroves that have been carried out in Lambadeuk Village, Peukan Bada District, Aceh Besar District at the tree level at stations 1 and 3 for Rhizophora apiculata and Rhizophora mucronata was $75.02 \%$. Species frequency value (Fi) at station 2 for Rhizophora apiculata was 75.02 ind. The large number of species was Rhizophora apiculata due to the condition of the substrate at the research site in the form of muddy sand. According to [14] that locations not far from the beach generally have a muddy sand type of sediment. Meanwhile, the location not far from the

\begin{tabular}{|c|c|c|c|c|c|c|c|c|c|c|}
\hline \multirow[t]{2}{*}{ Mangrove } & \multirow[t]{2}{*}{$\begin{array}{l}\text { Number } \\
\text { of Stands }\end{array}$} & \multirow[t]{2}{*}{$\begin{array}{l}\text { Transect } \\
\text { Area } \\
\text { (A) ha }\end{array}$} & $\begin{array}{c}\text { Specific } \\
\text { Density } \\
\text { (Di) }\end{array}$ & $\begin{array}{l}\text { Relative } \\
\text { Density }\end{array}$ & $\begin{array}{l}\text { Relative } \\
\text { Frequency }\end{array}$ & $\begin{array}{l}\text { Relative } \\
\text { Type } \\
\text { Frequenc }\end{array}$ & $\begin{array}{c}\text { Closure } \\
\text { Type }\end{array}$ & $\begin{array}{c}\text { Relative } \\
\text { Closure } \\
\text { Type }\end{array}$ & \multicolumn{2}{|c|}{$\begin{array}{l}\text { Important } \\
\text { Value Index } \\
\text { (INP) }\end{array}$} \\
\hline & & & Ind/ha & (RDi) & (Fi) & (RFi) & (Ci) & (Rci) & $\begin{array}{c}\text { Tree } \\
\text { and } \\
\text { sapling }\end{array}$ & $\begin{array}{c}\text { See } \\
\text { din } \\
\text { g }\end{array}$ \\
\hline $\begin{array}{c}\text { Rhizophora } \\
\text { apiculata }\end{array}$ & 36 & 0.01 & & & & & & & & \\
\hline
\end{tabular}
mainland has a sandy mud sediment type.

Table 1. Mangrove biological indeks value. 


\begin{tabular}{|c|c|c|c|c|c|c|c|c|c|c|}
\hline Station 1 & 8 & & 0.08 & 13.115 & 1 & 75.02 & 2.26 & 1.81 & 253.655 & $\begin{array}{r}250 \\
.04\end{array}$ \\
\hline Station 2 & 20 & & 0.2 & 100 & 100 & 75.02 & 10.96 & 8.77 & 183.789 & $\begin{array}{l}175 \\
.02 \\
\end{array}$ \\
\hline Station 3 & 8 & & 0.08 & 13.115 & 1 & 75.02 & 2.26 & 1.81 & 253.655 & $\begin{array}{r}250 \\
.04\end{array}$ \\
\hline $\begin{array}{l}\text { Rhizophora } \\
\text { mucronata }\end{array}$ & 116 & 0.01 & & & & & & & & \\
\hline Station 1 & 58 & & 0.53 & 86.89 & 1 & 75.02 & 2.26 & 1.81 & 253.655 & $\begin{array}{r}250 \\
.04 \\
\end{array}$ \\
\hline Station 2 & 0 & & 0 & 0 & 0 & 0 & 0 & 0 & 0 & 0 \\
\hline Station 3 & 58 & & 0.53 & 86.89 & 1 & 75.02 & 2.26 & 1.81 & 253.655 & $\begin{array}{r}250 \\
.04 \\
\end{array}$ \\
\hline Quantity & & & 1.42 & 300 & 104 & 375.1 & 20 & 16.01 & & \\
\hline
\end{tabular}

Table 2. Diversity, dominance, evenness and temperature.

\begin{tabular}{|c|c|c|c|c|c|c|c|c|c|}
\hline \multicolumn{3}{|c|}{ Diversity (H') } & \multicolumn{3}{c|}{ Dominance (C) } & \multicolumn{3}{c|}{ Evenness (E) } & $\begin{array}{c}\text { Temperatur } \\
\mathrm{e}\end{array}$ \\
\cline { 1 - 8 } & Sapling & Seeding & Tree & Sapling & Seeding & Tree & Sapling & Seeding & \\
\hline 0.09 & 0.04 & 0.02 & 0 & 0 & 0 & 0.01 & 0.01 & 0 & $29,51{ }^{\circ} \mathrm{C}$ \\
\hline 3 & 3 & 3 & 1 & 1 & 1 & 1 & 1 & 1 \\
\hline 0.09 & 0.04 & 0.02 & 0 & 0 & 0 & 0.01 & 0.01 & 0 \\
\hline 2.31 & 2.66 & 2.79 & 1 & 1 & 1 & 0.35 & 0.4 & 0.42 \\
\hline 0 & 0 & 0 & 0 & 0 & 0 & 0 & 0 & 0 \\
\hline 2.31 & 2.66 & 2.79 & 1 & 1 & 1 & 0.35 & 0.4 & 0.42 \\
\hline 1.35 & 1.45 & 1.49 & 0.5 & 0.5 & 0.5 & 0.2867 & 0.303 & 0.307 & \\
\hline
\end{tabular}

Species dominance is used to determine the concentration and distribution of dominant species. If the dominance is more than one species, then the dominance index value will increase. Furthermore, if several species dominate simultaneously, the dominance index value obtained will be low. [13]. Specific closure (Ci) is the area of the one type of closure in an area. The species closure value $(\mathrm{Ci})$ at stations 1 and 3 for Rhizophora apiculata and Rhizophora mucronata was $2.26 \mathrm{~m}^{2}$. The species closure value $(\mathrm{Ci})$ at station 2 for Rhizophora apiculata was $10.96 \mathrm{~m}^{2}$. The relative cover (RCi) of mangroves at stations 1 and 3 for Rhizophora apiculata and Rhizophora mucronata was $1.81 \%$ and at station 2 for Rhizophora apiculata was $8.77 \%$. The high relative cover of Rhizophora apiculata indicates that the presence of the mangrove species Rhizophora apiculata dominates the mangrove species in Lambadeuk Village, Peukan Bada District, Aceh Besar District. This is caused by the condition of the sandy mud substrate at the research site. Sandy mud substrate is suitable for the mangrove species Rhizophora apiculata because it has a high fertility rate, so that the mangrove species Rhizophora apiculata dominates in the Lambadeuk Village area and has relatively high cover values in almost all categories [21]. Saplings are an indicator of the sustainability of each mangrove species in the Lambadeuk area, where mangroves will grow and develop naturally without human intervention.

The Important Value Index for mangrove vegetation trees and seedlings can be obtained from the sum of the relative frequency, relative density, and relative cover of a vegetation expressed in percent (\%) [13]. From the results Table 1 , it can be seen that there are differences in the value of the Important Value Index in each category. The important value index (INP) tree and sapling of Rhizophora apiculata at station 1 and station 3 of $253.655 \%$ and station 2 of $183.789 \%$. While seedling of Rhizophora apiculata at station 1 and station 3 of $250.04 \%$ and station 2 of $175.02 \%$. The important value index (INP) tree and sapling of Rhizophora mucronata at station 1 and station 3 of $253.655 \%$. While seedling of Rhizophora mucronata at station 1 and station 3 of $250.04 \%$. The high Importance Value Index in the seedling category of Rhizophora Apiculata was caused by the condition of the muddy sand substrate [21]. The Important Value Index (INP) shows the range of the index that describes the community structure and distribution pattern of mangroves [21]. Furthermore, [21] stated that if the INP of the species obtained is high, then there are species that dominate a habitat. And this species is better able to adapt to its environment.

The high and low index of mangrove vegetation importance is caused by competition between species for nutrients and sunlight at the research site. Nutrients are very important for the stability of mangrove vegetation such as nitrate $\left(\mathrm{NO}_{3}\right)$ and phosphate $\left(\mathrm{PO}_{4}\right)$ [25]. Nitrate $\left(\mathrm{NO}_{3}\right)$ and phosphate $\left(\mathrm{PO}_{4}\right)$ are the most important nutrients that can determine the stability of vegetation growth. According to [12] stated that nutrient elements are absolute for organisms such as $\mathrm{N}$ and $\mathrm{P}$ because they cannot be replaced by other elements.

The value of $\mathrm{H}^{\prime}$ is a value that states how diverse a species is in a certain area, an area can be said to have moderate species diversity if the value of $\mathrm{H}^{\prime}$ exceeds 1 or equals 1 , if the value of $\mathrm{H}^{\prime}$ exceeds 3 , the species diversity obtained is high. However, if the $\mathrm{H}^{\prime}$ value 
found exceeds 0 but is less than 1 , it can be said that a community in the area has low species diversity.

\section{Conclusion}

The results of the study found 2 types of mangroves from the genus Rhyzophora. Which consists of 2 species Rhyzophora mucronata and Rhyzophora apiculata found in Lambadeuk village, Peukan Bada Regency, Aceh Besar district. RFi stations 1,2, and 3 with a value of 100, RFi stations 1 and 3 with a value of 150.04, and RFi for station 2 with a value of 75.02. For RCi stations 1 and 3 with a value of 36.2 , and RCi for station 2 with a value of 8.77. The highest INP is trees and saplings with a value of 253,655 , while the lowest INP is trees and saplings 183,789 . The highest INP of seedlings was 250.04 and the lowest INP of seedlings was 175.02. The highest value $\left(\mathrm{H}^{\prime}\right)$ from the category of trees, saplings, and seedlings was at station 2 with a value of 3 ind from the species Rhizophora apiculata. The highest value (C) was found at stations 1 and 3 species Rhizophora mucronata and Rhizophora apiculata with a value of 1 ind. The highest value (E) obtained from the categories of trees, saplings, and seedlings was at station 2 with a value of 1 ind from the species Rhizophora apiculata.

Acknowledgement. The writing of this manuscript is supported by the Matching Fund - Kedaireka funded by the Ministry of Education, Culture, Research, and Technology Indonesia awarded to the Research Center for Marine Sciences and Fisheries, Universitas Syiah Kuala.

\section{References}

1. A. Arief, Hakekat hutan dan pengaruhnya terhadap lingkungan. Yayasan Obor Indonesia. Jakarta (1994).

2. R. Azhar, M. Rusdi., M. Irham, A. Fuadi. Spatial distribution of mangrove using a geographic information system in Aceh Besar. IOP Conference Series: Earth and Environmental Science. International and National Symposium on Aquatic Environment and Fisheries. Banda Aceh. Indonesia. 674 (2021)

3. J. Z. Brower, C. Jerroid, V. Ende. Field and Laboratory Methods for General. Ecology. Mc Grow-Hill Science, New York (1997).

4. T. Cahyanto, R. Kuraesin, Jurnal Istek, 7, 2 (2013)

5. DKP Aceh Besar. Statistik Dinas Kelautan dan Perikanan Kabupaten Aceh Besar Tahun 2010. Dinas Kelautan dan Perikanan Kabupaten Aceh Besar. Jantho (2011)

6. R. Dahuri, J. Rias, S. P. Ginting, M. J. Sitepu, Pengelolaan Sumberdaya Wilayah Pesisir dan Lautan Secara Terpadu. Pradnya Paramita. Jakarta (2001).

7. Departemen Kehutanan. Statistik Kehutanan Indonesia, Frorestry Statistics of Indonesia 2003. Badan Planologi Kehutanan, Departemen Kehutanan, Jakarta (2004).
8. I. Dewiyanti, Identifikasi dan kelimpahan hama penyebab ketidakberhasilan rehabilitasi ekosistem mangrove Di Sekitar kawasan Aceh Besar dan Banda Aceh. Prosiding Seminar Nasional XXI PBI Aceh. PBI Aceh, Banda Aceh (2011).

9. S. English, C. Wilkinson, V. Baker, Survey manual for tropical marine resource. Townsville, Autralian Institute of Marin Science (1994)

10. M. F. Fachrul, Metode Sampling Bioekologi. Bumi Aksara. Jakarta (2007).

11. M. H. Ghufran, K. Kordi, K. Ekosistem Mangrove: Potensi, Fungsi dan Pengelolaan. Jakarta. Rineka Cipta (2012)

12. A. P. Hartoko, Soedarsono, A. Indrawati. Water Resour. Manag. 2, 2 (2013)

13. Indriyanto. Ekologi Hutan. Bumi Aksara. Jakarta. 138 (2006).

14. M. Irham, S. Adhla, C. Octavina, Depik 9, 1 (2020).

15. F. F. Muhsoni, JST 13, 3 (2020).

16. Y. R. Noor, M. Khazali, I. N. N. Suryadiputra, I. N. N. Panduan Pengenalan Mangrove di Indonesia: PHKA/WI-IP, Bogor (2006).

17. E. P. Odum, Dasar-Dasar Ekologi. Edisi Ketiga. Gadjah Mada University Press. Yogyakarta. 697 (1996)

18. E. Rochana, Ekosistem Mangrove Dan Pengelolaanya di Indonesia. IPB. Bogor (2001)

19. G. Raymond, N. Harahap, Soenarno. Agritek, 18, 2 (2010)

20. Y. P. Sari, M. L. S. Pessy, I. Lidiawati, Persepsi Masyarakat Pesisir dalam Pengelolaan Ekosistem Hutan Mangrove di Muara Gembong Bekasi Jawa Barat. Perenial, 14, (2) 78-85p (2018)

21. Supriharyono. Konservasi Ekosistem Sumberdaya Hayati di Wilayah Pesisir dan Laut Tropis. Pustaka Pelajar. Yogyakarta (2007)

22. Supriadi, A. Romadhon, A. Farid, J. Kelautan, 8, 1 (2015).

23. M. Warpur, Struktur Vegetasi Hutan Mangrove di Kampung Kunef Distrik Supiori Selatan Kabupaten Supiori. Paper presented at the Seminar Nasional Edusainstek (2018).

24. J. T. Wilhem, Dorris. Fundamental of Ecology. New York: Drenker Inc. (1986)

25. S. Yahra, Z. A. Harahap, E. Yusni, E., R. Leidonald, Jurnal Enggano, 5, 3 (2020). 